\title{
AKTIVITAS ANTI FUNGI PIGMEN MERAH Penicillium purpurogenum TERHADAP Fusarium oxysporum
}

\author{
S. Widayati ${ }^{1}$ dan T. Sopandi ${ }^{2}$ \\ ${ }^{1}$ Mahasiswa Prodi Biologi F.MIPA Universitas PGRI Adi Buana Surabaya \\ Email: Widayati755@gmail.com \\ ${ }^{2}$ Staf Pengajar Prodi Biologi F.MIPA Universitas PGRI Adi Buana Surabaya \\ Email: tatang_sopandi@yahoo.co.id
}

\begin{abstract}
Penicillium purpurogenum is known to be producing red pigment, pigment produced microbial activity, this research aims to demonstrate the activity of red pigment Penicillium purpurogenum antifungi against diameter and number of Fusarium oxysporum colonies, research done in the laboratory of Microbiology Adi Buana Surabaya University. This study used a randomized complete design (RAL) and Penicillium purpurogenum red pigment treatment concentrations of $0 \%, 0.5 \%, 1.0 \%, 1.5 \%$ and Ciprofloxacin $1.0 \%$. Each treatment was repeated 4 (four) times, the research was carried out in vitro on medium PDA. The results showed that the red pigment resistance power $P$. purpurogenum $1.5 \%$ a significant effect $(\mathrm{P}<0.05)$ against growth of fungi $F$. oxysporum and the number of colonies of fungis $F$. oxysporum compared red pigment resistance power $P$. purpurogenum $0 \%$ and $0.5 \%$. growth of fungi $F$. oxysporum on PDA media containing pigment red $P$. purpurogenum $1.5 \%$ significant $(\mathrm{P}<0.05)$ smaller than fungi growth $F$. oxysporum on PDA media containing pigment red $P$. purpurogenum $0 \%$ and $0.5 \%$. Research results can be concluded that use of red pigment of $P$. purpurogenum can inhibit growth and the number of colonies of fungis $F$. oxysporum.
\end{abstract}

Keyword: Red pigment, Penicilliumpur purogenum, Antifungi, Fusarium oxysporum.

\section{PENDAHULUAN}

Indonesia sebagai negara tropis memiliki iklim yang sangat mendukung pertumbuhan mikroorganisme, fungi merupakan mikroorganisme yang keberadaannya paling banyak, lebih dari 10.000 spesies fungi merupakan patogen terhadap tanaman (Agrios, 1997). Salah satu penyakit yang disebabkan oleh fungi adalah penyakit layu Fusarium yang disebabkan oleh fungi Fusarium sp. adanya serangan fungi ini menyebabkan terjadinya penurunan produksi cabai merah di Malang dengan kerugian yang ditimbulkan hingga jutaan rupiah (Astuti, 2010). Fungi Fusarium oxysporum adalah salah satu jenis fungi patogen yang dapat dorman selama 30 (tigapuluh) tahun sebelum melanjutkan virulensi dan menginfeksi tanaman dan menyebabkan kondisi yang disebut layu Fusarium (Agrios.1996). Fungi F.oxysporum f.sp. lycopersici mampu menginfeksi tanaman sejak dalam fase pembibitan sehingga dapat mengakibatkan tanaman mati dan gagal panen (Semangun, 2001). 
Fungi F.oxysporum juga menyerang jaringan bagian vaskuler dan mengakibatkan kelayuan pada tanaman inangnya dengan cara menghambat aliran air pada jaringan xylem (De Cal et al.,2000).

Pengendalian penyakit fungi dengan fungisida sintetik ke dalam tanah hanya dapat menekan penyakit layu Fusarium untuk beberapa bulan (Allabouvette et al., 1996). Fungi dapat menyebabkan kerugian besar terutama pada varietas yang rentan dan pada kondisi lingkunganyang sesuai (Agrios, 2005). Penggunaan pestisida sintetik yang berlebihan juga dapat menimbulkan dampak buruk bagi kesehatan dan lingkungan (UPI,1996). Selain itu fungisida sintetik juga mencemari lingkungan dan menyebabkan kematian manusia di dunia hingga mencapai $40 \%$ (Irawan, 2006).

Pengendalian hayati terhadap patogen tanaman, baik terhadap bagian tanaman di permukaan tanah maupun di dalam tanah, melibatkan mikroba antagonis atau agensia pengendali hayati, patogen tanaman yang dikendalikannya tidak saja terbatas pada kelompok fungi dan bakteri, juga nematoda patogen tanaman, penggunaan agensia pengendali hayati tersebut sudah banyak dilakukan, terutama terhadap patogen tanaman yang sukar dijangkau keberadaannya oleh agensia kimia sintetis, yaitu fungisida, bakterisida, dan nematesida, beberapa macam agensia pengendali hayati dapat dikelompokkan ke dalam fungi, bakteri dan khamir antagonis (Soesanto, 2008).

Penicillium merupakan fungi yang hidup secara saprofit dan berkembang biak secara vegetatif dengan konidia. Fungi ini umumnya ditemukan pada roti, kentang, kacang, atau makanan busuk lainnya.Fungi P.purpurogenum dapat memproduksi pigmen merah pada substrat dimana dia tumbuh (Sen, 1963), sering digunakan sebagai pewarna pangan.Pigmen yang dihasilkan oleh fungi umumnya termasuk golongan antharaguinone, karotenoid, flavonoid, kuinin dan rubramin (Sharma, et al., 2012). Beberapa spesies fungi Penicillium juga memiliki aktivitas antimikroba terhadap fungi Saccharomyces cerevisieae dan bakteri Escherichia coli dan Bacillus subtilis (Arisanti et al., 2012).

Penelitian, Sekitar 800 jenis antibiotik dihasilkan oleh fungi, fungi penghasil antibiotik yang terkenal diantaranya adalah Penicilium menghasilkan penisilin, griseofulvin, serta beberapa fungi lain seperti Aspergillus menghasilkan fumigasin (Suwandi 1989). Penicillium sp. dan Aspergillus sp. dilaporkan juga menghasilkan senyawa metabolit sekunder yaitu lovastin yang berfungsi sebagai anti hiperkolestrolemia (Aryantha et al., 2004). Penisilin ditemukan oleh Alexander Fleming pada tahun 
1929. Fleming memperlihatkan bahwa pada suatu cawan agar yang diinokulasikan

dengan

Staphylococcus aures telah terkontaminasi oleh sejenis jamur dan koloni jamur tersebut dikelilingi oleh suatu zona yang jernih, menunjukkan adanya penghambatan pertumbuhan bakteri (Pelczar and Chan, 2005). Namun demikian penelitian dengan aktivitas pigmen $P$. purpurogenum sebagai anti fungi F.oxysporum belum banyak dipublikasikan. Penelitian ini bertujuan untuk membuktikan aktivitas antifungi pigmen merah $P$. purpurogenum terhadap $F$. oxysporum.

\section{METODE PENELITIAN}

Penelitian mengenai aktivitas antifungi pigmen merah $P$. purpurogenum terhadap $F$. oxysporum dilakukan sebagai upaya membuktikan daya hambat.

\section{Produksi pigmen merah}

$P$. purpurogrnum diperoleh dari koleksi laboratorium mikrobiologi Fakultas Matematika dan Ilmu Pengetahuan Alam Universitas PGRI Adi Buana Surabaya. Sebanyak 5 liter media kentang dibagi menjadi 10 bagian masing-masing $500 \mathrm{ml}$ dan dimasukkan kedalam labu elemeyer berukuran $500 \mathrm{ml}$ kemudian disterilisasikan menggunakan autoklaf dengan suhu $121^{\circ} \mathrm{C}$ selama 15 menit tekanan 1 atm setelah di sterilisasi didinginkan pada suhu ruang. Isolat $P$. purpurogenum1 loop penuh di inokulasi kedalam masingmasing media cair. Semua media cair yang telah di inokulasi dengan $P$. purpurogenum di inkubasi selama 7 hari pada suhu $28^{\circ}-29^{\circ} \mathrm{C}$ dalam keadaan gelap dan di agitasi pada $100 \mathrm{rpm}$.Setelah inkubasi media cair hasil fermentasi disaring menggunakan kertas saring whatman no 1 kemudian dilakukan destilasi pada suhu $70^{\circ}-80^{\circ} \mathrm{C}$ sehingga diperoleh cairan kental, cairan kental tersebut dikeringkan dalam oven pada suhu $60^{\circ}-80^{\circ} \mathrm{C}$ sampai beratnya konstan.

\section{Uji daya hamabat}

Fusarium

oxysporum

diperoleh dari Fakultas Pertanian Universitas Gajah Mada. Uji daya hambat anti Fusarium dilakukan menggunakan metode difusi cakram kertas.Sebanyak $500 \mathrm{ml}$ media padat PDA yang telah di sterilisasi dituangkan ke dalam 25 cawan petri kemudian didinginkan pada suhu ruang. Setelah media PDA padat isolate $F$. oxysporum $(0,1 \mathrm{ml})$ disebarkan diatas media menggunakan tongkat penyebar. Sebanyak 5 cakram kertas masingmasing dicelupkan ke dalam larutan $P$. purpurogenum dengan konsentrasi $0 \mathrm{mg} / 100 \mathrm{ml}$ (aquades), $0,5 \mathrm{mg} / 100 \mathrm{ml}, 1,0 \mathrm{mg} / 100 \mathrm{ml}, 1,5$ $\mathrm{mg} / 100 \mathrm{ml}$ pigmen $P$. purpurogenum dan kontrol positif $0^{+}$ (Ciprofloxacin $1.0 \mathrm{mg} / 100 \mathrm{ml}$ ) semua kertas cakram ditempelkan dalam media PDA dengan cara 
diukur sama. Semua media PDA yang telah diinokulasi dengan $F$. oxysporum dan diberi kertas cakram diinkubasi dalam keadaan terbalik pada suhu $27^{\circ}-28^{\circ} \mathrm{C}$ selama 3 hari.Diameter daerah jernih pada masing-masing kertas cakram diukur dengan menggunakan jangka sorong sebagai daerah hambatan.

\section{Uji reduksi}

Sebanyak $200 \mathrm{ml}$ media cair PDB yang telah di sterilisasikan dituangkan ke dalam 22 tabung reaksi. Isolate $F$. oxysporum dilakukan pengenceran dengan menggunakan aquades sehingga mendapatkan $F$, oxysporum $0,10^{-6}$ dimasukkan masing-masing $1,0 \mathrm{ml}$ ke dalam tabung reaksi yang berisi media cair PDB. Kemudian dimasukan larutan pigmen merah $P$. purpurogenum dengan konsentrasi 0 $\mathrm{mg} / 100 \mathrm{ml}$ (aquades), 0,5 mg/100 $\mathrm{ml}, 1,0 \mathrm{mg} / 100 \mathrm{ml}, 1,5 \mathrm{mg} / 100 \mathrm{ml}$ pigmen $P$. purpurogenum dan kontrol positif $0^{+}$(Ciprofloxacin 1,0 $\mathrm{mg} / 100 \mathrm{ml}$ ) ke dalam masingmasing tabung reaksi yang sudah diisi media cair PDB dan fungi $F$. oxysporum dan diinkubasi selama 3 hari pada suhu $27^{\circ}-28^{\circ} \mathrm{C}$. Setelah itu dituangkan pada cawan petri yang berisi media padat (PDA) lalu diinkubasi selama 3 hari pada suhu ruang.

Perhitungan hambatan diameter pertumbuhan fungi $F$. oxysporum

Sebanyak $500 \mathrm{ml}$ media padat PDA yang sudah disterilisasi dituangkan ke dalam 25 cawan petri kemudian dicampur dengan larutan pigmen merah $P$. purpurogenum dengan konsentrasi $0 \mathrm{mg} / 100 \mathrm{ml}$ (aquades), 0,5 mg/100 ml, 1,0 $\mathrm{mg} / 100 \mathrm{ml}, 1,5 \mathrm{mg} / 100 \mathrm{ml}$ pigmen $P$. purpurogenum dan kontrol positif $0^{+}$(Ciprofloxacin 1,0 mg/100 ml) ke dalam masing-masing cawan petri yang berisi media padat PDA kemudian didinginkan pada suhu $27^{\circ}-28^{\circ}$ C. Setelah media PDA padat $F$. oxysporum diletakkan di tengahtengah permukaan media PDA dengan menggunakan jarum ose kemudian diinkubasi dan diukur diameter koloni $F$. oxysporum setiap hari dengan menggunakan jangka sorong

\section{HASIL DAN PEMBAHASAN Hasil penelitian Uji daya hambat}

Hasil penelitian pada (Gambar 4.1) menunjukkan bahwa pigmen merah $P$. purpurogenum mempunyai daya hambatan terhadap fungi $F$. oxysporum. Hasil penelitian menunjukkan bahwa daerah jernih pada pemberian pigmen merah $P$. purpurogenum dengan konsentrasi $1,5 \mathrm{mg} / 100 \mathrm{ml} \quad(0.92 \pm 0.06 \quad \mathrm{~cm})$ signifikan $(\mathrm{P}<0,05)$ lebih tinggi dibandingkan dengan daerah jernih pada konsentrasi $1,0 \mathrm{mg} / 100 \mathrm{ml}$ $(0.70 \pm 0.01 \mathrm{~cm}), \quad$ daerah jernih konsentrasi $\quad 0,5 \quad \mathrm{mg} / 100 \mathrm{ml}$ $(0.53 \pm 0.01 \mathrm{~cm})$, dan pada daerah jernih konsentrasi $0 \mathrm{mg} / 100 \mathrm{ml}$ $(0.50 \pm 0.00 \mathrm{~cm})$. Daerah jernih pada pemberian pigmen merah $P$. 
purpurogenum dengan konsentrasi $1,0 \quad \mathrm{mg} / 100 \mathrm{ml} \quad(0.70 \pm 0.01 \quad \mathrm{~cm})$ signifikan $(\mathrm{P}<0,05) \quad$ lebih tinggi dibandingkan dengan daerah jernih pada konsentrasi $0,5 \mathrm{mg} / 100 \mathrm{ml}$ $(0.53 \pm 0.01 \mathrm{~cm})$, dan daerah jernih konsentrasi $0 \mathrm{mg} / 100 \mathrm{ml}(0.50 \pm 0.00$ $\mathrm{cm})$, dan daerah jernih pada pemberian pigmen merah $P$. purpurogenum dengan konsentrasi $0,5 \mathrm{mg} / 100 \mathrm{ml}(0.53 \pm 0.01 \mathrm{~cm})$ tidak berbeda signifikan $\quad(\mathrm{P}<0,05)$ dibandingkan dengan daerah jernih pada konsentrasi $0 \mathrm{mg} / 100 \mathrm{ml}$ $(0.50 \pm 0.00 \mathrm{~cm})$. Namun demikian, daerah jernih pada konsentrasi 1,5 $\mathrm{mg} / 100 \mathrm{ml}$ pigmen merah $P$. purpurogenum $(0.92 \pm 0.06 \mathrm{~cm})$ signifikan lebih rendah dibandingkan dengan daerah jernih pada ciprofloxacin $1,0 \mathrm{mg} / 100 \mathrm{ml}$ $(1.49 \pm 0.13 \mathrm{~cm})$.

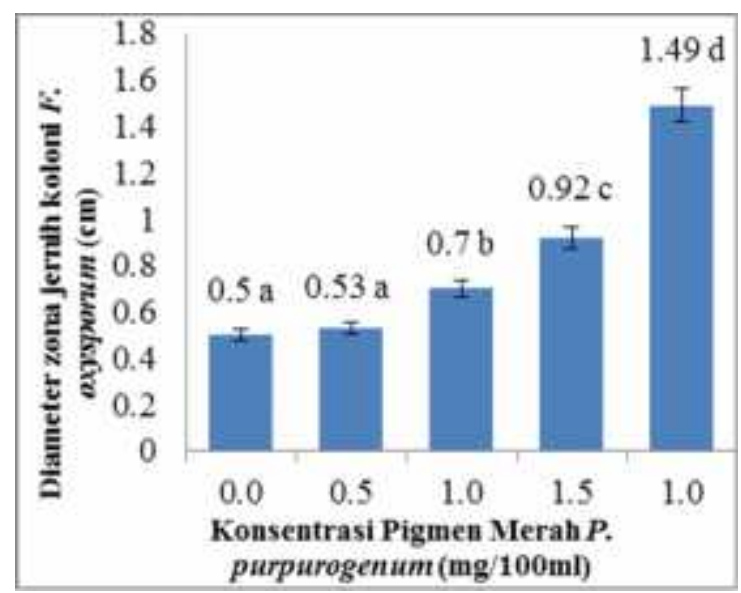

Gambar.4.1 Rata-Rata Diameter Zona Jernih Koloni F. oxysporum dengan pemberian konsentrasi pigmen merah $P$. purprogenum yang berberda $(\mathrm{mg} / 100 \mathrm{ml})$.

Jumlah koloni fungi fusarium oxysporum

Hasil penelitian menunjukkan bahwa pigmen merah $P$. purpurogenum signifikan $(\mathrm{P}<0,05)$ dapat menghambat pertumbuhan fungi $F$. oxysporum. Rata-rata jumlah koloni fungi $F$. oxysporum yang diberi pigmen merah disajikan pada (Gambar.4.2). Penelitian menunjukkan bahwa jumlah koloni $F$. oxysporum pada pemberian pigmen merah $P$. purpurogenum dengan konsentrasi $1,5 \mathrm{mg} / 100 \mathrm{ml}$ $(1.56 \pm 0.04 \mathrm{log} \mathrm{cfu} / \mathrm{ml})$ tidak berbeda signifikan $(\mathrm{P}<0,05)$ dibandingkan dengan jumlah koloni $F$. oxysporum pada konsentrasi $1,0 \mathrm{mg} / 100 \mathrm{ml}$ $(1.63 \pm 0.01 \quad \log \mathrm{cfu} / \mathrm{ml})$, namun signifikan $(\mathrm{P}<0,05)$ lebih rendan dengan jumlah koloni $F$. oxysporum konsentrasi $\quad 0,5 \quad \mathrm{mg} / 100 \mathrm{ml}$ $(1.70 \pm 0.01 \log \mathrm{cfu} / \mathrm{ml})$, dan jumlah koloni $F$. oxysporum konsentrasi 0 
$\mathrm{mg} / 100 \mathrm{ml}(1.85 \pm 0.05 \log \mathrm{cfu} / \mathrm{ml})$. Jumlah koloni $F$. oxysporum pada pemberian pigmen merah $P$. purpurogenum dengan konsentrasi $1,0 \quad \mathrm{mg} / 100 \mathrm{ml} \quad(1.63 \pm 0.01 \quad \log$ $\mathrm{cfu} / \mathrm{ml})$ signifikan $(\mathrm{P}<0,05)$ lebih rendah dibandingkan dengan jumlah koloni $F$. oxysporum pada konsentrasi $\quad 0,5 \quad \mathrm{mg} / 100 \mathrm{ml}$ $(1.70 \pm 0.01 \log \mathrm{cfu} / \mathrm{ml})$, dan jumlah koloni $F$. oxysporum konsentrasi 0 $\mathrm{mg} / 100 \mathrm{ml}(1.85 \pm 0.05 \mathrm{log} \mathrm{cfu} / \mathrm{ml})$, dan jumlah koloni $F$. oxysporum pemberian pigmen merah $P$. purpurogenum dengan konsentrasi $0,5 \quad \mathrm{mg} / 100 \mathrm{ml} \quad(1.70 \pm 0.01 \quad \log$ $\mathrm{cfu} / \mathrm{ml})$ signifikan $(\mathrm{P}<0,05) \quad$ lebih rendah dibandingkan dengan jumlah koloni $F$. oxysporum pada konsentrasi $0 \mathrm{mg} / 100 \mathrm{ml}(1.85 \pm 0.05$ $\log \mathrm{cfu} / \mathrm{ml})$. Namun demikian, jumlah koloni $F$. oxysporum pada konsentrasi $1,5 \mathrm{mg} / 100 \mathrm{ml}$ pigmen merah $P$. purpurogenum (1.56 \pm 0.04 $\log \mathrm{cfu} / \mathrm{ml}$ ) signifikan lebih tinggi dibandingkan dengan jumlah koloni $F$. oxysporum pada ciprofloxacin 1,0 $\mathrm{mg} / 100 \mathrm{ml}(1.53 \pm 0.04 \mathrm{log} \mathrm{cfu} / \mathrm{ml})$.

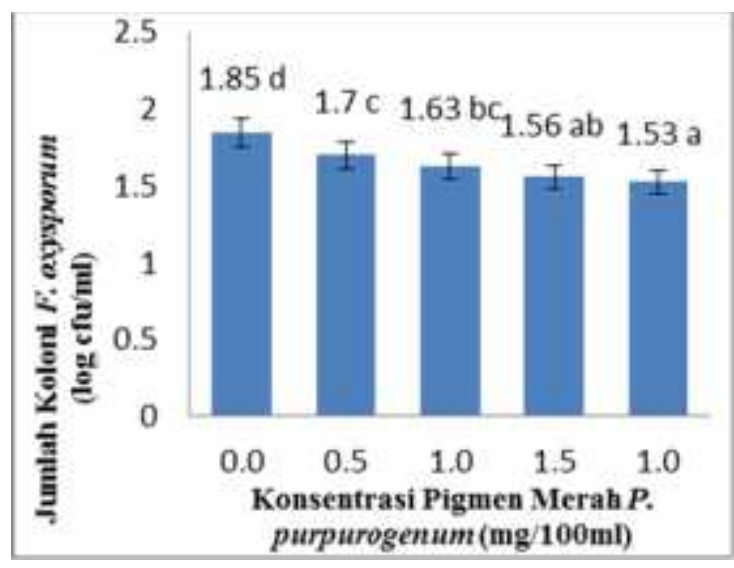

Gambar.4.2.Rata-Rata Jumlah Koloni $F$. oxysporum dengan pemberian konsentrasi pigmen merah $P$. purprogenum yang berberda $(\mathrm{mg} / 100 \mathrm{ml})$.

\section{Pembahasan}

Hasil penelitian menunjukkan bahwa pigmen merah $P$. purpurogenum dapat menghambat pertumbuhan fungi $F$. oxysporum pada konsentrasi 1,0 dan $1,5 \%$ dengan diameter hambatan sebesar 0,70 dan $0,92 \mathrm{~cm}$. daya hambat tertinggi diperoleh pada konsentrasi
1,5\%. Daya hambat pertumbuhan $F$. oxysporum oleh pigmen merah $P$. purpurogenum disebabkan oleh senyawa aktif yang terdapat pada pigmen tersebut. Pigmen merah $P$. purpurogenum menghasilkan senyawa aktif yaitu mitosrubin, mitosrubinol, purpurogenone dan pencolide (Mapari et al 2006). 
Pencolide yang diproduksi oleh strain penicillium, menunjukkan aktivitas bakteriostatik dan fungisida (Lucas et al., 2007). Senyawa aktif mitorubrinol dan Purpurogenone, yang diproduksi oleh fungi filamen digunakan sebagai pewarna (Soccol et al., 2006).

Hasil penelitian ini juga menunjukkan bahwa pigmen merah $P$. purpurogenum dapat mengurangi jumlah koloni $F$. oxysporum pada media PDA. Berkurangnya produksi jumlah koloni $F$. oxysporum ini diduga disebabkan oleh senyawa aktif pencolide yang ada pada pigmen merah $P$. purpurogenum (Mapari et al 2006). Pencolide yang diproduksi oleh strain penicillium, menunjukkan aktivitas bakteriostatik dan fungisida (Lucas et al., 2007).

Berdasarkan penelitian terdahulu menunjukkan bahwa pigmen yang dihasilkan oleh $P$. resticulosum dapat dikategorikan sebagai pigmen toksisitas rendah (Sopandi, and Wardah, 2012). Pigmen dari Penicillium memiliki toksisitas yang beragam, bergantung pada senyawa pigmen. Pigmen omponent seperti atrovenetin dan norherqueinone dari $P$. antrovenetum (Raistrick et al, 1958), antrovenetin dan herquinones dari $P$. herquei (Robinson et al 1992), antrakuinon dari $P$. citrinum (Duran et al., 2002), phoenicin dari $P$. antrosanguineum, xantho- epocin dari $P \quad$ Brevicompactum, anthraquinone deriva- tives arpink red dari P. oxalicum (Mapari et al.,
2005), mitosrubin, mitosrubinol dan purpurogenone dari

$P$. purpurogenum (Mapari et al 2006) telah dikenal sebagai pigmen nontoksik. Di sisi lain, komponen pigmen beracun meliputi citrinine dari P. citrinum (Duran et al. 2002). Kultur cair skala besar spesies Penicillium sclerotiorum menyebabkan isolasi pencolide, sclerotiorin dan isochromophilone. senyawa pencolide dan isochromophilone disaring dengan uji difusi disk untuk mengamati wheatear, mereka juga berkontribusi untuk bioaktivitas ekstrak. Sclerotiorin dimasukkan dalam studi bioaktivitas untuk memperluas skrining antibakteri. Dalam uji disk, senyawa pencolide dan sclerotiorin menunjukkan zona inhibisi terhadap semua bakteri Gram positif dan Gram negatif yang diuji ( $S$. pyogenes, $S$. aureus, $S$. typhimurium dan $E$. coli ) dan terhadap ragi $C$. albicans ( Lucas et al., 2007).

\section{KESIMPULAN}

Berdasarkan hasil penelitian dan pembahasan didapatkan kesimpulan sebagai berikut:

1. Pigmen merah $P$. purpurogenum terbukti dapat menghambat pertumbuhan fungi F. oxysporum.

2. Pigmen merah $P$. purpurogenum terbukti dapat mengurangi jumlah koloni fungi F. oxysporum. 
DAFTAR PUSTAKA

Agrios, G.N. 1996. Ilmu Penyakit Tumbuhan. Yogyakarta: Gadjah Mada University Press

Agrios, G.N. 2005. Plant Pathology - Fifth Edition. Departemen of Plant Pathology. University of Florida. United States of America.

Allabouvette R, Lemanceae P and Steinberg C. 1996. Biological Control of FusariumWilts : Opputunities for developing a Comercial product. P 193-211.

Arisanti S, Nengah D K, and Maya S. 2012. Uji Antimikroba Isolat Kapang Tanah Wonerejo Surabaya. Digiib ITS.

Surabaya http://digilib.its.ac.id/public/I TS-undergraduate-17615paper-pdf. 04 januari 2017

De Cal A, Garcia-Lepe $\mathrm{R}$ and Melgarejo P. 2000. Induced Resistance by Penicillium oxalicum Againt $F$. oxysporum f.sp.licopersici: Histological studies of infected and induced tomato stem. Phytopathology 90:260-268.

Duran N, Teixeira MF, De Conti R, Esposito E. 2002. Ecological-friendly pigment from fungi. Crit Rev Food Sci Nutr.42(1):53-66.

Irawan, D. 2006. Bawang Merah Dan Pestisida. http://www.bahanpang.sumut prov.go.id/ardet.php?idx_hot news=31. BERITA BKP SUMUT

Lucas, Esther MF., Mateus C., Monteiro de Castro., and Jacqueline A. Takahashi. 2007.

Atividade antimikrobiana de esclerotiorina, isocromofilona VI e pencolídeo, metabo- litos secundários de Penicillium sclerotiorum van Beyma isolado de solo do cerrado brasileiro. Braz J. Microbiol. Vol.38 no.4 São Paulo Oct./Dec. 2007 diambil dari Http://dx.doi.org/10.1590/S1 517-83822007000400036 (02 agustus 2017)

Mapari SAS, Meyer AS, Thrane U. $2006 . \quad$ Colorimetric characterization for comparative analysis of fungal pigment and natural colorants. $J$ Agric Food Chem. 54(19):7027-7035. doi: 10.1021/jf062094n.

Mapari SAS, Nielsen KF, Larson TO, Frisvad JC, Meyer AS, Thrane U. 2005. Exploring fungal biodiversity for production of water soluble pigment as potential natural food colorant. Curr Opin Biotechnol. 16(2):231-238. doi:10.1016/j.copbio.2005.03 .004

Pelczar, M.J. and E.C.S. Chan. 2005.

Dasar-dasar 
Mikrobiologi. UI-Press. Soccol CR, Vandenberghe LPS, Jakarta

Raistrick H, Stossl A. 1958. Studies in the biochemistry of microorganisms 104. Metabolites of Penicillium atrovenetum G. Smith $\beta$ nitropropionic acid, a major metabolite. Biochem $J$. 68:647-653

Robinson N, Wood K, Hylands PJ, Gibson TM, Weedon CJ, Covill. 1992. Blue pigment of Penicillium herquei. $J$ NatProd. 55(6):814-817. Doi:10.1021/np5008a019.

Semangun H. 2001. Pengantar Ilmu Penyakit Tumbuhan. Yogyakarta: Gajah Mada University

Sen, S.N. 1963 Pigment Formation by Penicillium rubrum Stoll. http://www.nature.com/natur e/journal/v199/n4888/abs/19 9071a0.html

Sharma, D., Gupta, C., Aggarwal, S., and Nagpal, N. 2012. Pigmen extracition from fungus for textile dyeing. Indian journal of Fibre \& Textile Research, 37: 68-73
Rodrigues C, Pandey A. 2006. Perspektif Baru untuk Produksi Asam Sitrat dan Aplikasi. Makanan Technolology dan Bioteknologi. 44 (2): 141149.

Soesanto, Lukas. 2008. Pengantar Pengendalian Hayati Penyakit Tanaman. Jakarta: PT. Rajawali Grafindo Persada

Sopandi, T., and Wardah, 2012. Sub-Acute Toxicity of Pigment Derived from Penicillium resticulosum in Mice. microbiology indonesia. Vol 6, No 1, March 2012. Diambil dari: http://jurnal.permi.or.id/inde x.php/mionline. (24 juli 2017)

Suwandi, U. 1992. Mekanisme Kerja Antibiotik. Cermin Dunia Kedokteran No. 76. Jakarta. Pusat Penelitian dan Pengembangan. P.T. Kalbe Farma. 